\title{
KULTTUURIPOLITIIKAN VISIOT JA JATKUVUUS
}

\author{
Katsaus Suomen puolveiden kevään 2019 \\ eduskuntavaaliohjelmiin ja tuoreimpiin kulttuuripoliittisiin \\ erityisohjelmiin
}

\section{Visions and continuity of cultural policy-A look into the 2019 parliamentary election programmes of Finland's political parties and their cultural political special programmes}

Political parties are significant cultural political influencers: they are in key positions to define cultural policy and how it is implemented in society. Parties have attitudes and interests toward culture that they inform about through their different programme documents such as broad general programmes, more narrow art and cultural policy and other policy sector specific programmes, and election programmes that delineate parties' goals for the following electoral period. In this review, we concentrate on the latter ones. Through the parties' parliamentary election programmes of 2019 and their most recent cultural policy special programmes we examine the parties' cultural political discourses and their visions of public cultural policy goals. The review shows that although there are differences between the parties' cultural political discourses' scope and content, all parties are commited to the prevailing system of public cultural policy. This reflcets the strong position that central administration holds in Finnish cultural policy. However, the parties' viewpoints in defining culture and cultural political goals expand the limits of this sector administration that is in many aspects well established.

\section{Aluksi: puolueet ja kulttuuripolitiikka}

Eduskuntavaalit keväällä 2019 lisäsivät tuoretta julkista keskustelua puolueiden taide- ja kulttuuripoliittisista näkemyksistä. Yleisradion huhtikuussa 2019 tekemään kyselyyn vastasivat kaikki eduskuntapuolueet. Kyselyssä kulttuuribudjetin korottamista kannatti enemmistö eduskuntapuolueista lukuun ottamatta Perussuomalaisia ja Suomen Kristillisdemokraatteja. Budjetin kasvattamisen sijaan Suomen Keskusta ehdotti uutta kulttuuria ja luovia aloja tukevaa rahastoa. ${ }^{1}$ Useat puolueet korostivat taiteen vapautta politiikasta, osa myös virkamiesvallasta. Esimerkiksi Suomen Sosialidemokraattisen Puolueen (SDP) mukaan: "Ei ole poliitikkojen, virkamiesten tai muiden rahoittajien tehtävä määritellä taiteen sisältöjä tai tavoitteita." Perussuomalaiset vaikuttivat Ylen kyselyssä puolueista selkeimmin kritisoivan nykyisen järjestelmän toimintaa ja näkevän sen ideologisena: "Valtion kulloistenkin ihanteiden mukaiset "oikeamieliset" projektit eivät tarvitse veroeuroja. [...] Rahoitusjärjestelmää tulee kaiken kaikkiaan tuulettaa ja purkaa ideologista ja politisoitunutta toimintakulttuuria." (Gustafsson, 2019.) Perussuomalaisten näkökulmasta nykyjärjestelmä ei vastaa kansan kulttuuritarpeisiin, joskaan puolue ei kyselyssä esittänyt uusia visioita.

Puolueiden kulttuuripoliittisilla kannanotoilla on merkitystä, sillä puolueilla on keskeinen asema kulttuurin määrittelyissä ja rajaamisessa, lainsäädännön muotoilussa sekä julkisen tuen suuntaamisessa. Samaan aikaan puolueilla 
on hyvin erilaisia asenteita, tavoitteita ja visioita siitä, mihin julkisessa kulttuuripolitiikassa tulisi tähdätä. Eroihin vaikuttavat osaltaan puolueiden taustalla olevat ideologiat. ${ }^{2}$

Puolueiden kulttuuripoliittisista näkemyksistä saa tietoa niiden ohjelmista. Puolueilla on moninaisia ohjelmia: laajoja yleisohjelmia, rajatusti taide- ja kulttuuripolitiikkaa ja muita politiikkalohkoja koskevia erityisohjelmia sekä vaalikauden tavoitteita esitteleviä vaaliohjelmia. Tässä katsauksessa keskitymme kevään 2019 eduskuntavaalien vaaliohjelmiin sekä niitä täydentävinä puolueiden tuoreimpiin kulttuuripoliittisiin erityisohjelmiin.

Katsauksessa tarkastelemme puolueiden kulttuuripoliittisia visioita seuraavien kysymysten kautta:

I. Miten puolueohjelmien kulttuuripuhunnat eroavat toisistaan määrällisesti, rakenteellisesti ja sisällöllisesti?

II. Miten kulttuurihallinnon vaikutus näkyy puolueohjelmissa?

III. Esittävätkö puolueet uusia kulttuuripoliittisia avauksia vai pyrkivätkö ne lähinnä kehittämään nykyistä järjestelmää?

Vaikka puolueet ovat keskeisiä kulttuuripoliittisia vaikuttajia, niitä on tarkasteltu kulttuuripolitiikan tutkimuksessa viime vuosina suhteellisen vähän. Aiemmassa tutkimuksessa on todettu puolueiden historiallisesti keskeinen asema suomalaisen kulttuuripolitiikan muodostumisessa (Mertanen, 2008). Puoluepoliittiset painotukset vaikuttavat niin valtion kuin paikallishallinnon tasolla. Valtion tasolla puolueohjelmien on todettu vaikuttavan eduskuntaryhmien toimintaan taiteen ja kulttuurin edistämisessä (Tuomikoski-Leskelä, 1977, s. 180; vrt. myös Nousiainen, 1998, s. 71). Anita Kankaan (1991, s. 32-35, s. 38-39) tutkimuksessa etenkin keskisen Suomen kunnissa nousi esiin vasemmistoenemmistöisten kuntien halukkuus tukea kulttuuritoimintaa kulttuurilautakuntien kautta. Hallinnon vaikutus suomalaiseen kulttuuripolitiikkaan on havaittu vahvaksi. Kulttuurilehti Mustekalan Taide ja puoluepolitiikka -teemanumerossa (1:2015) Pauli Rautiainen katsoi suomalaisen taidepolitiikan olleen ennemmin hallintoa kuin politiikkaa. Politiikan sisältöön liittyvää puhetta on "suorastaan vältelty". (Kemppi, 2015.) Aiemmassa tutkimuksessa on laajemminkin todettu, kuinka suomalaisesta julkisesta kulttuuripolitiikasta "puuttuu politiikka" tai että järjestelmää on kehitetty rakenteellista jähmeyttä tuottavalla "pienten askelten politiikalla"3 (Rautiainen, 2008; Saukkonen, 2014).

Seuraavassa luvussa luomme yleiskuvan kulttuuripolitiikkaan puolueiden ohjelmatyössä. Kolmannessa luvussa tarkastelemme kulttuuripolitiikkaa puolueiden tuoreimmissa eduskuntavaaliohjelmissa sekä kulttuuripoliittisissa erityisohjelmissa. Viimeisessä luvussa kokoamme yhteen keskeiset havainnot ja pohdimme hallinnon ja politiikan suhdetta suomalaisessa kulttuuripolitiikassa.

\section{Kulttuuripolitiikka puolueiden ohjelmatyössä}

\section{Puolveet kulttuuripoliittisina toimijoina}

Puolueet vaikuttavat kulttuuripolitiikkaan monin tavoin. Puolueista koostuva kansanedustuslaitos säätää taidetta ja kulttuuria koskevat lait sekä viimeistelee ja hyväksyy valtion budjetin. Puolueiden edustajat vaikuttavat lainsäädäntötyössä keskeisessä asemassa olevissa valiokunnissa. Etenkin kulttuurikysymyksissä valmistelevana tahona on jo vuosikymmenet toiminut sivistysvaliokunta, joka käsittelee muun muassa koulutukseen, tieteeseen, kulttuuriin ja viestintään liittyviä asioita. Käytännön elämässä puolueiden vaikutuspiiri ulottuu huomattavasti eduskuntataloa laajemmalle yhteiskunnan ja julkishallinnon rakenteisiin (esim. Nousiainen, 1998, s. 31).

Kulttuuripolitiikka liittyy kulttuurin organisoitumiseen yhteiskunnallisessa toiminnassa (ks. Kangas \& Pirnes, 2015, s. 23). Se muodostuu prosessissa, jossa eri toimijat rakentavat ja rajaavat kuvaa kulttuurisista ilmiöistä ja olosuhteista (ks. Häyrynen, 2015, s. 11). Kulttuuripolitiikan piiriä voidaan rajata suppeasti tai laajasti. Molemmista näkökulmista puolueet ovat kes- 
keisiä toimijoita.

Suppeasta näkökulmasta kulttuuripolitiikka samaistetaan ensisijaisesti valtioon. Suomalaisen kulttuuripolitiikan keskiössä on perinteisesti nähty kulttuurista vastaava juridis-hallinnollinen ja institutionalisoitunut järjestelmä (ks. Sokka, 2014; Häyrynen, 2015). Siten kulttuuripolitiikka sijoittuu etenkin opetus- ja kulttuuriministeriön hallintosektorille (ja siellä vielä rajatummin taide- ja kulttuuripolitiikan osastolle). Tästä näkökulmasta poliittiset puolueet vaikuttavat kulttuuripolitiikkaan ohjaamalla ministeriöiden työtä hallitusohjelman kautta. Ministerit nousevat yleensä jonkin hallituspuolueen riveistä. Ministeri on ministeriön ylin päätöksentekijä ja suunnannäyttäjä huolimatta valtiohallinnon instituutioiden jatkuvuudesta ja omasta poliittisesta vaikutusvallasta. Tarkasteltaessa valtiovallan vaikutusta kulttuurielämään on huomattava valtion voivan vaikuttaa kulttuuriin monella eri tavalla. Kulttuuripolitiikkaan kytkeytyvät läheisesti myös monet muut politiikkasektorit, esimerkiksi koulutus-, sosiaali- ja talouspolitiikan hallinnonalat, ns. "kulttuuripolitiikan rajavyöhykkeet" (ks. Häyrynen, 2015; Gronow, 1976).

Laajemmin ymmärrettynä kulttuuripolitiikka on kenen tahansa sen toteuttajan asenne kulttuuriin "liitettynä valmiuksiin ja haluun ajaa tätä asennetta ympäristössään” (Häyrynen, 2015, s. 11). Tästä näkökulmasta poliittiset puolueet ovat sektoriksi rajatun julkisen kulttuurihallinnon ulkopuolisia - joskin käytännössä monin tavoin siinä kiinni olevia - toimijatahoja, joilla on omia kulttuuriin kohdistuvia pyrkimyksiään. Näistä pyrkimyksistä saadaan tietoa puolueiden erilaisten ohjelmien kautta.

\section{Puolveohjelmien rooli}

\section{Ohjelmat puolveen omakuvina ja tavoitteiden linjaajina}

Puolueohjelmat kuvaavat sekä puolueiden yleistä kulttuuripoliittista intressiä sekä konkreettisia toimenpiteitä. Yleisellä tasolla ohjelmat toimivat puoluekuvan luojina ja poliittisina tekoina, joilla on merkitystä puolueen sisäisille prosesseille sekä puolueen kannattajakunnalle. Ne edustavat tietyn aikakauden poliittista kielenkäyttöä (Aarnio \& Kanerva, 1995, s. 4). Käytännössä ohjelmat kuvaavat puolueiden uskomuksia, periaatteita ja toiminnallisia tavoitteita (Paastela \& Paloheimo, 2006, s. 5). Puolueohjelmiin sisältyy konkreettisia vaatimuksia ja lupauksia sekä teoreettisia väitteitä, tulkintoja ja toteamuksia (Borg, 1965), joilla yritetään vaikuttaa eri intressiryhmiin ja hankkia niiden kannatusta (Tuomikoski-Leskelä, 1977, s. 178). Ohjelmissaan puolueet tarjoavat kansalaisille tietoa ja näkemyksiä yhteiskunnallisista asioista ja poliittisia tulevaisuuden vaihtoehtoja, perinteisesti puolueideologiaan kehystettynä (Wiberg, 2006, s. 48-49). Ohjelmien kielen kautta tapahtuva poliittinen vaikuttaminen heijastuu poliittiseen toimintaan (esim. Borg, 1965).

Käytännössä nykyisten puolueiden näkemykset ovat samankaltaistumisen ja valtiollistumisen (ks. esim. Sundberg, 2012, s. 133) myötä lähentyneet toisiaan. Puolueiden ohjelmissa vaaditaan usein samansuuntaisia asioita ja käsitellään samankaltaisia teemoja. Moni puolue pyrkii irtautumaan perinteisestä jaosta vasemmisto-, keskusta- ja oikeistopuolueisiin. Puolueideologiat ovat valtaa keskittävässä järjestelmässä väistyneet sivummalle yleispätevän tavoitteenasettelun tieltä: ideologisia jakolinjoja on etenkin hallituspolitiikassa korvattu näennäisen neutraalilla ja hallinnollisella suunnittelukielellä (Mykkänen, 2017, s. 97-98). Tästä huolimatta puolueohjelmien käsitteet, lausumat, painotukset ja arvot luovat eroja puolueiden välille (esim. Karlsson \& Wiberg, 2010). Kulttuuripolitiikka on puolueille eräs mahdollinen keino nostaa omaa profiiliaan ja erottautua muista.

Puolueilla on tyypiltään erilaisia ohjelmia. Kaikki ohjelmat pyrkivät tulevaisuuden hahmottamiseen (Lappalainen, 2006, s. 50), mutta niiden asema vaihtelee. Ohjelmatutkimuksen parissa puolueohjelmia on ryhmitelty eri tavoin (ks. mm. Borg, 1965, 1995; Paastela \& Paloheimo, 2006; Lappalainen, 2006). Yleisohjelmat ovat periaateohjelmia, jotka koostuvat puolueiden yleisistä aatteellisista periaatteista. Erityisohjelmat taas käsittelevät täsmällisemmin 
kulttuuripolitiikan tapaisia rajattuja politiikkalohkoja. Erityisohjelmissa on siten mahdollisuus käsitellä täsmällisemmin ja monipuolisemmin tiettyyn politiikan osa-alueeseen liittyviä visioita. Tavoiteohjelmat koskevat puolueiden lähiajan tavoitteita. Niihin kuuluu esimerkiksi ennen eduskuntavaaleja hyväksytty, seuraavaa vaalikautta varten laadittu vaaliohjelma. (Paastela \& Paloheimo, 2006, s. 5.)

Vaaliohjelmat ovat kulttuuripoliittisesti merkityksellisiä, sillä niillä on keskeinen merkitys hallitusohjelman suuntaamisessa: vaaliohjelmat kuvaavat puolueiden seuraavan vaalikauden keskeisiä toiveita. Hallitusohjelman tehtävänä on sitouttaa hallituksessa vaikuttavat puolueet etukäteen vaalikauden aikana toteutettaviin tavoitteisiin ja toimenpiteisiin (Mykkänen, 2017). Hallitusohjelmaan nousee eri suhteessa hallituspuolueiden ohjelmissaan listaamia tavoitteita, jotka hallituspuolueet voivat jakaa. Samalla kun puolueet pyrkivät tekemään myönnytyksiä hallitusyhteistyön saavuttamiseksi, vaalilupaukset ja -ohjelmat tapaavat laimentua. Suomessa politiikan ohjaus on hallituskeskeistä: hallitusohjelman ulkopuolelle jääneitä asioita on käytännössä vaikea saada poliittisille asialistoille.

\section{Puolveiden sitoutuminen kulttuuripoliittisen järjestelmän periaatteisiin}

Kulttuuripolitiikka tuli 1960-luvulla osaksi kehittyvän suomalaisen hyvinvointivaltion yhteiskuntapolitiikkaa (esim. Kangas, 1999). Tämän myötä valtion opetus- ja kulttuurihallinto alkoi laajentua ja eriytyä. Yhteiskunnallisuus toi taiteelle poliittista ja taloudellista tukea (Tuomikoski-Leskelä, 1977, s. 186, 284). Samalla puolueet ryhtyivät ottamaan aiheeseen kantaa.

Kehitys heijastui puolueiden ohjelmatyöhön. Puolueet näkivät taiteella ja kulttuurilla myös poliittisen funktion. Puolueohjelmissa korostettiin etenkin omien viiteryhmien taideharrastusten tarpeita: keskustapuolueella tämä oli maaseutuväestö, SKDL:lla ja SDP:lla puolestaan työväestö. (Mertanen, 2008, s. 126.) Sisällöllisesti puolueiden yleisohjelmat alkoivat mukailla valtion opetus- ja kulttuurihallinnon laajenemista ja eriytymistä (Tuomikoski-Leskelä, 1977, s. 186). Niiden sivistyspolitiikka jakautui selvemmin koulutus- ja kulttuuripolitiikkaan. Esimerkiksi korkein hengenviljely, tiede ja taide saivat omat ohjelmakohtansa. Samalla puolueiden taidepoliittiset ohjelmavaatimukset yhtenäistyivät. Kulttuuri- ja taidepolitiikka nähtiin osana yleistä yhteiskuntapolitiikkaa. Puoluekohtaiset intressit ja ideologiset painotukset väistyivät, ja taiteella nähtiin yleisesti tehtävä "ihmisen ja kansakunnan kulttuurin kohottajana” (Tuomikoski-Leskelä, 1977, s. 190).

Suomalaiselle kulttuuripoliittiselle mallille ovat ominaisia oikeudellinen sääntely ja institutionaalisuus, jotka heijastuvat sen pitkäikäisyyteen (Saukkonen, 2014). Kulttuuripoliittinen päätöksenteko ja ohjaus pysyneet perusrakenteiden luomisen jälkeen varsin vakaina. Lainsäädäntö on varmistanut taiteen ja kulttuuripalvelujen aseman ja resursoinnin hallituspolitiikan muutoksista riippumatta.

Myös puolueet ovat sitoutuneet järjestelmään: 1960-luvulta lähtien puolueita on esimerkiksi puoluetuen ja puoluelain kautta kytketty kiinteämmin valtioon. Samalla ne ovat menettäneet luonnettaan kansanliikkeinä ja alkaneet muistuttaa valtioon kytkettyjä organisaatioita. (Nousiainen, 1998, s. 48.)

Käytännössä poliitikkojen ja politiikan mahdollisuuksia rajaavat erilaiset keskitetyn vallan muodot (esim. Mykkänen, 2017): keskushallinnon tulosohjaus, uusbyrokratisoituminen, kehysbudjetointi ja lainsäädännöstä johtuvat hallinnolliset automaatit sekä tulossopimuksiin ja -mittareihin, ulkoistamisiin, kilpailuttamiseen ja markkinakilpailun suojaamiseen kytkeytyvät monimutkaiset säännöt. Virkamiesvalta korostuu myös kulttuuripolitiikassa. Simo Häyrynen (2006, s. 17) näkee opetus- ja kulttuuriministeriön vastuulle kuuluvasta hallintojärjestelmästä tulleen jopa "omalakinen ja usein oman sektorinsa sisäisten ongelmien ja suhteiden sekä näistä kysymyksistä välittömästi syntyneiden kysymysten puimiseen keskittyvä’. Pauli Rautiaisen mukaan 2000-luvulla niukkenevien resurssien aikakaudella myös kulttuuripolitiikassa ovat korostuneet mittaaminen ja budjetit. Lakien säätämisestä on siirrytty talousarviopäätösten teke- 
miseen sekä erilaisten hankkeiden tukemiseen. (Kemppi, 2015.)

Pasi Saukkosen (2014) kuvauksen perusteella Suomessa "kulttuuripolitiikkaa on kehitetty, mutta vailla erityistä dramatiikkaa ja vahvaa koordinaatiota, niin ikään vailla kokonaisvaltaista visiota siitä, mihin kansallisessa kulttuuripolitiikassa pidemmällä aikavälillä tähdätään”. Puolueohjelmissa tämä on jo pitkään tarkoittanut melko vakaata sitoutumista 1960- ja 70-luvuilla alkunsa saaneeseen, 1980-luvulla edelleen laajennettuun ja 1990-luvulla institutionaalisesti ja lainsäädännöllisesti (esimerkiksi museoita, teattereita ja orkestereita koskevan valtionosuusjärjestelmän lainsäädäntö) viimeisteltyyn kulttuuripolitiikan järjestelmään.

\section{Ohjelmatyön yhteiskunnallisuus}

Puolueiden ohjelmatyö ei tapahdu tyhiössä, vaan se saa vaikutteita toimintaympäristöstä, hallinnosta ja muusta yhteiskunnallisesta toiminnasta. Puolueet kartoittavat toimintaympäristön muutoksia ja tulevaisuuskehitystä omiin tarpeisiinsa tutkimusyhteisöjen, ajatushautomoiden ja ohjelmatyöryhmien avulla. Eeva Aarnion (1998, s. 260) mukaan perinteisiä ideoiden lähteitä puolueille ovat olleet esimerkiksi sisarpuolueet, etu- ja aatepoliittiset järjestöt, hallintoviranomaiset, julkiset laitokset kuten yliopistot ja korkeakoulut, teollisuuden ja kaupan järjestöt, maatalouden järjestöt, ammattiyhdistysliike, erilaiset kotimaiset ja kansainväliset organisaatiot, yritykset sekä mediat.

Puolueohjelmien traditiot eroavat toisistaan. Sosialistisessa ja kommunistisessa traditiossa ohjelmatyöllä on perinteisesti ollut keskeinen asema (Aarnio, 1998, s. 20). Myös ohjelmien laatimisprosessien muodot ja laajuus vaihtelevat eri puolueiden välillä. Esimerkiksi KD:n tuoreimman kulttuuripoliittisen ohjelman (2009) laadintaan osallistui ohjelman mukaan kahdeksan hengen työryhmän lisäksi seitsemän muuta henkilöä. SDP:n uuden kulttuuripoliittisen ohjelman (2018) kirjoitti niin ikään puolueen perustama työryhmä, mutta sisältöön pyydettiin ideoita yli 1500 vastausta tuottaneella jäsenkyselyllä. Lisäksi SDP:n ohjelmaa kommentoivat kulttuurialan etujärjestöt ja esilukivat kulttuurialan ammattilaiset.

Kulttuuripolitiikassa sektorihallinnolla on keskeinen asema. Toiminnan suunnittelu ja toimeenpano kantaa ministeriöissä yli hallituskausien. Kulttuuribudjetista on muodostunut varsin vakiintunut, yksityiskohtainen ja monimutkainen. Virkamiehillä on usein sisältökysymyksissä etulyöntiasema suhteessa vaihtuviin ministereihin. Virkamiestyönä ministeriöissä syntyneet aloitteet voivat päätyä ensinnäkin puolueohjelmiin ja toisaalta edelleen hallitusohjelmaan, jolla valtioneuvosto luo poliittisen agendan myös hallituskauden kulttuuripolitiikalle (Kangas \& Pirnes, 2015, s. 37). Ennen kevään 2019 eduskuntavaaleja, syksyllä 2018 opetus- ja kulttuuriministeriö lähetti puolueille hallitusohjelmatavoitteensa (OKM 2018). Niissä esitetään kolmessa kategoriassa (taiteen ja kulttuurin rahoitus ja infrastruktuuri; taiteet ja luovat alat; saatamme kulttuurin, kulttuuriperinnön ja taiteen kaikkien käytettäväksi) erilaisia linjauksia lisämäärärahatarpeineen. Nämä linjaukset heijastuvat myös puolueiden vaaliohjelmatyöhön.

\section{Kulttuuripolitiikka puolveiden ohjelmissa}

Puolueiden välillä on eroa siinä, miten kulttuuripolitiikkaa niiden ohjelmatyössä käsitellään. Kevään 2019 eduskuntavaaliohjelmissaan Vihreä liitto (jatkossa vihreät), Perussuomalaiset ja Sininen tulevaisuus eivät mainitse kulttuuria lainkaan. Muut tuolloiset eduskuntapuolueet mainitsevat kulttuuripolitiikan mutta eri laajuudessa. Kulttuuri on näkyvästi esillä Suomen Sosialidemokraattisen Puolueen (jatkossa SDP) ja Vasemmistoliiton vaaliohjelmissa. Puolueet ovat omistaneet kulttuuripolitiikalle vaaliohjelmista kokonaan oman osionsa. Kulttuurin mainitsevat Suomen ruotsalainen kansanpuolue (jatkossa RKP), Kansallinen Kokoomus (jatkossa kokoomus), Suomen Keskusta (jatkossa keskusta) sekä Suomen Kristillisdemokraatit (jatkossa KD), jotka käsittelevät aihetta osana muita vaaliohjelmansa osa-alueita. (Taulukko 


\section{1.)}

Kaikilla eduskuntapuolueilla on Perussuomalaisia ja Sinistä tulevaisuutta lukuun ottamatta kulttuuripoliittinen erityisohjelmansa. Voimassa olevista kulttuuripoliittisista erityisohjelmista vanhin on KD:n kulttuuripoliittinen ohjelma vuodelta 2009. Tuoreimpia ovat SDP:n, Vasemmistoliiton, vihreiden, keskustan ja kokoomuksen erityisohjelmat vuosilta 2018 ja 2019. (Taulukko 1.)

On huomattava, että tarkasteltavien ohjelmien asema on erilainen. Vaaliohjelmat ovat puolueiden keskeisiä, seuraavaa vaalikautta koskevia toiveita, joista hallitusohjelmaan tiivistetään hallituspuolueiden jakamat linjaukset. Vaaliohjelmiin nostetut tavoitteet kuvaavat, kuuluuko kulttuuripolitiikka puolueen prioriteetteihin ja jos kuuluu, millaisia puolueen kulttuuripoliittiset kärjet ovat. Vaaliohjelmista poiketen kulttuuripoliittisissa erityisohjelmissa keskitytään juuri kyseiseen politiikkalohkoon. Siten erityisohjelmien kulttuuripoliittiset sisällöt ovat huomattavasti vaaliohjelmia laajempia ja kattavampia. Erityisohjelmista nousevat myös usein puolueiden vaaliohjelmien kulttuuripoliittiset kärjet.

Vaali- ja erityisohjelmien raja ei ole täysin tarkka. Keskustan kulttuurilinjaus ja kokoomuksen kulttuurivisio koskevat vaaliohjelman tapaan seuraavaa vaalikautta. Siten linjaukset on kytketty osaksi puolueiden eduskuntavaaliohjelmia. Myös vihreät linjaa kulttuuripolitiikkaa vaaliohjelmaa täydentävässä poliittisessa tavoiteohjelmassaan vuosille 2019-2023. Nämä linjaukset ovat kuitenkin vaaliohjelmasta erillisiä dokumentteja, joita käsitellään tässä kulttuuripoliittisina erityisohjelmina.

\section{Ohjelmien kulttuuripoliittiset sisällöt}

\section{Kevään 2019 eduskuntavaaliohjelmat}

Kevään 2019 eduskuntavaaliohjelmissa kaikki tuolloiset eduskuntapuolueet vihreitä, Perussuomalaisia ja Sinistä tulevaisuutta lukuun ottamatta mainitsevat kulttuuripolitiikan. Keskeinen ero on, että vasemmistopuolueet SDP ja Vasemmistoliitto käsittelevät vaaliohjelmissaan

\begin{tabular}{|c|c|c|c|}
\hline \multirow[b]{2}{*}{ Puolue } & \multicolumn{2}{|c|}{ Eduskuntavaaliohjelma 2019} & \multirow[b]{2}{*}{$\begin{array}{l}\text { Viimeisin kulttuuripoliittinen } \\
\text { erityisohjelma }\end{array}$} \\
\hline & $\begin{array}{l}\text { Kulttuuripolitiikka- } \\
\text { linjauksia }\end{array}$ & $\begin{array}{l}\text { Kulttuuripolitiikalle } \\
\text { oma osionsa }\end{array}$ & \\
\hline Suomen Keskusta & Kyllä & $\mathrm{Ei}$ & 2018 (kulttuurilinjaus) \\
\hline Kansallinen Kokoomus & Kyllä & $\mathrm{Ei}^{*}$ & 2019 (kulttuurivisio) \\
\hline $\begin{array}{l}\text { Suomen Sosialidemokraatti- } \\
\text { nen Puolue (SDP) }\end{array}$ & Kyllä & Kyllä & 2018 (kulttuuripoliittinen ohjelma) \\
\hline Vasemmistoliitto & Kyllä & Kyllä & 2018 (kulttuuripoliittinen ohjelma) \\
\hline $\begin{array}{l}\text { Suomen ruotsalainen kansan- } \\
\text { puolve (RKP) }\end{array}$ & Kyllä & $\mathrm{Ei}$ & 2015 (kulttuuripoliittinen ohjelma) \\
\hline $\begin{array}{l}\text { Suomen Kristillisdemokraatit } \\
\text { (KD) }\end{array}$ & Kyllä & $\mathrm{Ei}$ & 2009 (kulttuuripoliittinen ohjelma) \\
\hline Vihreä liitto & Ei & $\mathrm{Ei}^{* *}$ & 2018 (kulttuuripoliittinen ohjelma) \\
\hline Perussuomalaiset & $\mathrm{Ei}$ & $\mathrm{Ei}$ & $\mathrm{x}^{* * *}$ \\
\hline Sininen tulevaisuus & $\mathrm{Ei}$ & $\mathrm{Ei}$ & $x$ \\
\hline \multicolumn{4}{|c|}{ * Vaaliohjelmassa linkki puolveen kulttuurivisioon } \\
\hline \multicolumn{4}{|c|}{$\begin{array}{l}\text { Puolue julkaissut kulttuuripolitiikkaa linjaavan poliittisen tavoiteohjelman vuosille } 2019-2023 \\
\text { ** Puolueelta ei löydy kulttuuripoliittista ohjelmaa, mutta esimerkiksi keskustelua herättänyt kulttuuripoli- } \\
\text { tiikkaosio eduskuntavaaliohjelmassa } 2011 \text {. }\end{array}$} \\
\hline
\end{tabular}

Taulukko 1. Katsauksen aineisto. Puolveiden kulttuuripoliittiset linjaukset vaaliohjelmissa 2019 ja viimeisimpien kulttuuripoliittisten erityisohjelmien julkaisuvuosi. 
Suomen Keskusta

Kansallinen Kokoomus

Suomen Sosialidemokraattinen Puolue (SDP)

Vihreä liitto

$\begin{array}{ll} & \text { Kulttuuripoliittinen osio otsikolla "Toteutamme taiteen prosenttiperiaatteen". Si- } \\ & \text { joitettu osioon "Meidän Suomessamme luodaan työtä panostamalla osaamiseen. } \\ \text { Vastaamme työn murrokseen ja yhä nopeampaan teknologiseen kehitykseen". } \\ \text { Vaaliohjelman teemoina mm. taiteen ja kulttuurin rahoituksen lisäys, taiteilija- } \\ \text { apurahojen korottaminen, valtionosuusuudistus, taiteen prosenttiperiaate, julkisen } \\ \text { sektorin teettämät taiteen ja kulttuurin alan työt. }\end{array}$

Perussuomalaiset

Ei kulttuurilinjauksia eduskuntavaaliohjelmassa

Kulttuuripolitiikkaa otsikon "Hyvinvoiva Suomi" / "Ett välmående Finland" alla. Teemoina hyvät vapaa-ajan harrastukset hyvinvointia kehitettäessä, riittävä liikunta- ja kulttuuritarjonta, kulttuuri-, urheilu-, kotiseutu- ja yhdistystoiminta identiteetin ja sosiaalisen pääoman vahvistajina, kulttuurin tukeminen mutta ei johtaminen, kulttuurilaitosten toimintaedellytysten turvaaminen, monimuotoisuus, laajempi kulttuuritarjonta, Svenska Teaternin status kansallisena näyttämönä.

Kulttuuripolitiikkaa otsikon "Laadukasta koulutusta, kulttuuria ja liikuntaa kai-

Suomen Kristillisdemokraatit (KD)

Sininen tulevaisuus kille". Teemoina koulujen yhteydessä järjestettävä kerho- ja harrastustoiminta, kristillinen kulttuuriperintö kasvatuksessa, kulttuuripalveluiden saavutettavuus, taidelaitosten resursointi, kulttuurin hyvinvointivaikutukset.

Ei kulttuurilinjauksia eduskuntavaaliohjelmassa

\section{Taulukko 2. Puolveiden vaaliohjelmien kulttuuripoliittinen puhunta.}

taide-, taiteilija- ja kulttuuripolitiikkaa laajemmin kuin muut kulttuuripolitiikkaa käsittelevät puolueet. (Taulukko 2.)

SDP:n vaaliohjelman kulttuuripolitiikkapuhunta on kaikista nykyisistä eduskuntapuolueista monipuolisinta. Myös Vasemmistoliitto linjaa kattavasti taide- ja kulttuuripolitiikkaa. Eduskuntavaaliohjelmansa kulttuuripuhunnassa Vasemmistoliitto tuntuu kohdistavan sanomansa erityisesti taiteen ja kulttuurin kentille,
SDP lisäksi kansalaisille taiteen ja kulttuurin kokijoina ja tekijöinä. Keskustan, kokoomuksen, RKP:n ja KD:n vaaliohjelmissa kulttuuripolitiikkaa linjataan suppeasti yksittäisinä lausumina osana muuta vaaliohjelmaa ja yleisiä yhteiskuntapoliittisia tavoitteita, ilman erillistä kulttuuriosiota. (Taulukko 2.)

Moni kevään 2019 eduskuntavaaliohjelmien tavoite vastaa opetus- ja kulttuuriministeriön hallitusohjelmatavoitteita (OKM, 2018). Yh- 
tenäiset teemat korostavat kulttuurihallinnon rakenteiden ja virkamiesten vahvaa vaikutusta. Yhteisiä tavoitteita opetus- ja kulttuuriministeriön hallitusohjelmassa sekä puolueiden eduskuntavaaliohjelmissa ovat vos-uudistus, taiteilija-apurahat, rahapelisidonnaisuuskeskustelu (Veikkaus ja jakosuhdelaki), prosenttiperiaate, kuntien valtionosuudet ja mahdollisuudet tarjota kulttuuri- ja taidepalveluita, lasten ja nuorten kulttuuriharrastukset ja -harrastuskerhot, taiteen perusopetus sekä luovat alat. Opetus- ja kulttuuriministeriön hallitusohjelmatavoitteisiin kuuluu myös tavoite kulttuurin rahoitusosuuden nostamisesta prosenttiin valtion budjetista. Tavoite viittaa opetus- ja kulttuuriministeriön Taide ja kulttuuri -budjettiluokkaan, joka on ollut noin 450 miljoonaa euroa eli 0,8 prosenttia koko valtion budjetista. ${ }^{4}$ Eduskuntavaaliohjelmissaan tätä prosentin tavoitetta tukevat SDP ja Vasemmistoliitto. Tätä kautta vasemmistopuolueet korostavat julkisen sektorin vastuuta ja rahoituksen lisäämistä. ${ }^{5}$

\section{Tuoreimmat kulttuuripoliittiset erityisohjelmat}

Puolueiden kulttuurilinjaukset ja muut kulttuuripoliittiset erityisohjelmat täydentävät ja laajentavat kuvaa puolueiden kulttuuriasenteista ja -tavoitteista. Taulukossa 1 kuvataan kaikkien eduskuntapuolueiden tuoreimmat kulttuuripoliittiset erityisohjelmat. Kokoomuksen ja keskustan ohjelmat ovat tiiviitä, vaalikautta koskevia linjauksia. Vasemmistoliiton, vihreiden, SDP:n, KD:n ja RKP:n ohjelmat taas ovat kattavampia erityisohjelmia. Vaihteleva laajuus heijastuu kulttuuripoliittisten erityisohjelmien vaihteleviin sisältöihin ja ehdotettuihin toimenpiteisiin (ks. Liite 1).

Sana- ja sivumäärältään laajimpia ovat vuonna 2018 julkaistut vihreiden, Vasemmistoliiton ja SDP:n kulttuuripoliittiset erityisohjelmat. Niissä kuvataan tavoitteiden lisäksi asiantuntevasti nykyistä suomalaista kulttuuripoliittista järjestelmää, sen historiaa sekä puolueen suhdetta kulttuuriin. Kaikki ohjelmissa esitetyt tavoitteet ja toimenpiteet on koottu liitteen 1 taulukkoon.
Vihreiden ohjelmadokumentti on puolueista yksityiskohtaisin: ohjelmassa esitetään eri tavoitekokonaisuuksien alla yhteensä 124 toimenpidettä. Ne liittyvät esimerkiksi kulttuuripalveluiden saavutettavuuteen, omaehtoiseen kulttuuritoimintaan, kulttuuriseen monimuotoisuuteen ja tasa-arvoon, valtionosuusjärjestelmään, kulttuuriin ja koulutukseen, rakennetun ympäristön laatuun, kulttuuriin ja hyvinvointiin sekä monimuotoiseen kulttuuriperintöön. Vastaavat teemat heijastuvat myös puolueen kulttuuria koskeviin tavoitelinjauksiin. Vihreiden tavoitelinjaukset vuosille 2019-2023 liittyvät taiteen perusopetukseen, kulttuurisiin oikeuksiin, taiteilijoiden toimeentuloon ja työllisyyteen, taiteen rahoituksen vahvistamiseen, kulttuuripalveluiden saavutettavuuteen, Yleisradion toiminnan turvaamiseen sekä taiteen ja kulttuurin prosenttiperiaatteeseen.

Vasemmistoliiton ohjelma on tarkkuudeltaan lähes vihreiden ohjelmaa vastaava. Ohjelmassa linjataan yhteensä 66 erilaista toimenpidettä. Keskeisiä teemoja ovat taiteilijoiden asema, saavutettavuus ja yhdenvertaisuus, kulttuurinen moninaisuus, taiteen ja kulttuurin rakenteet, saavutettavuus sekä kulttuuriperintö.

SDP:n ohjelma ei vihreiden ja Vasemmistoliiton ohjelmadokumenteista poiketen aseta tarkkoja tavoitteita, vaan tarjoaa koko 2020-luvun kattavan vision kulttuurin merkityksestä ja tulevaisuudesta. SDP:n ohjelman loppuun kirjoitettu kappale kulttuuripoliittisen ohjelman roolista kuvaa näiden ohjelmien merkitystä puolueille ja roolia puolueen toiminnassa yleisemminkin. Huomionarvoista on, että SDP suuntaa ohjelmansa ensisijaisesti jäsenille ja päättäjille ja erikseen toivoo myös muiden lukevan ohjelman. Tämä kuvaa kiinnostavasti puolueohjelmien kohderyhmiä ja niihin kohdistuvia odotuksia: julkisuudesta huolimatta niitä on harvemmin osoitettu laajemmin kaikkien kansalaisten luettavaksi.

KD:n ja RKP:n erityisohjelmat linjaavat kulttuuripolitiikkaa vasemmistopuolueita ja vihreitä suppeammin. KD:n viimeisin kulttuuripoliittinen erityisohjelma on vuodelta 2009. Sen keskeisiä teemoja ovat valtion vastuu kulttuurin edistämisessä, kulttuurinen monimuo- 
toisuus, kehityspolitiikka ja kehitysyhteistyö, kulttuuri osana kasvatusta ja koulutusta sekä kulttuuripolitiikka kunnissa ja maakunnissa. RKP:n ohjelmassa vuodelta 2015 taas korostuvat saavutettavuus, osaaminen, media sekä kulttuuri osana yhteiskuntaa.

Keskustan vuonna 2018 julkaistut kulttuuritavoitteet ja kokoomuksen vuonna 2019 julkaistu kulttuurivisio ovat laajaa tavoiteohjelmaa suppeampia kulttuurilinjauksia, joissa on vaaliohjelmia vastaava painotus tulevaan vaalikauteen. Keskusta jatkaa linjauksellaan vuoden 2015 kevään kulttuurilinjauksensa tyyliä esittämällä napakasti numeroituna ja temaattisiin kokonaisuuksiin jaoteltuna puolueen keskeisimmät kulttuuritavoitteet vaalikaudelle sekä vaalikauden "kärkihankkeen". Keskusta on jakanut linjauksensa temaattisesti viiteen, selkeästi jäsenneltyyn tavoitealueeseen: kulttuuripolitiikan kehittämiseen, taide- ja taiteilijapolitiikkaan, lapsiin ja nuoriin, kestävään kehitykseen sekä "kärkitavoitteeseen" (rahasto). Yhteensä puolue esittää 11 toimenpidettä tavoitteiden edistämiseksi. Kokoomuksen kulttuuriohjelma on suppeahko ja sanamäärältään lähes täsmälleen keskustan kulttuurilinjauksen mittainen. Kokoomuksen tavoitealueet ovat kulttuurin rahoitus, luovat alat sekä saatavuus, joiden alla puolue esittää yhteensä 22 keinoa edistää päätavoitteita.

\section{Lopuksi: visiot ja jatkuvuus}

"...oleellistahan olisi tuoda esiin se, millä nämä jalot perusajatukset käytännön politiikan tasolla toteutetaan. Siitä en löytänyt mitään konkreettista." (Kantokorpi 2015.)

Katsaus puolueiden eduskuntavaaliohjelmiin ja tuoreimpiin kulttuuripoliittisiin erityisohjelmiin osoitti, että kulttuuripolitiikan asema puolueiden ohjelmatyössä vaihtelee. Etenkin vasemmistopuolueet linjaavat vaali- ja erityisohjelmissaan kulttuuripolitiikkaa monipuolisesti. Perussuomalaiset ja Sininen tulevaisuus taas eivät käsittele kulttuuripolitiikkaa kevään 2019 eduskuntavaaliohjelmissaan eikä niillä ainoina eduskuntapuolueina ole kulttuuripoliittista erityisohjelmaa. Erot kertovat prioriteeteista puolueiden kiinnostuksen kohteissa ja ohjelmatyössä. Puolueohjelmien näkökulmasta erityisesti vasemmistopuolueet (sekä tavoite- ja erityisohjelmansa perusteella vihreät) pitävät kulttuuripolitiikkaa tärkeänä teemana ja viestivät tästä ohjelmien kautta omille kannattajilleen ja muulle lukijakunnalle.

Hallinnon keskeinen asema suomalaisessa kulttuuripolitiikassa heijastuu myös puolueiden ohjelmatyöhön. Kevään 2019 eduskuntavaaliohjelmissa näkyy lukuisia opetus- ja kulttuuriministeriön hallitusohjelmatavoitteita vastaavia teemoja. Tämä korostaa virkakoneiston ja hallinnon keskeistä asemaa ja vallankäyttöä kulttuuripolitiikassa. Pyrkivätkö puolueet vakuuttamaan ohjelmillaan ja asiantuntemuksellaan kansalaisten sijaan ennemminkin hallintoa?

Puolueohjelmien eksplisiittisesti taide- ja kulttuuripolitiikkaa koskevat visiot vastaavat valtaosin kulttuuripolitiikan nykytilaa: painotus on voimakkaasti järjestelmän jatkuvuudessa kuten valtionosuusuudistuksen edistämisessä. Puolueet tuntuvat pääosin sitoutuvan suomalaisen hyvinvointivaltion kulttuuripolitiikan periaatteisiin (vrt. Mertanen, 2008, s. 126): taiteen autonomian takaamiseen, taiteilijatukeen, kulttuuriperinnön suojaamiseen sekä kulttuurisen tasa-arvon periaatteeseen esimerkiksi kulttuuripalveluiden saatavuuden ja alueellistamisen kautta. Ohjelmat sisältävät myös 2000-luvun myötä keskeiseksi nousseita tavoitteita kulttuurin taloudellisista mahdollisuuksista ja hyvinvointivaikutuksista sekä luovien alojen tukemisesta. Katsaus vahvistaa siten aiemman tutkimuksen havaintoja suomalaisen kulttuuripolitiikan keskittymisestä hallintoon politiikan sijaan.

Toisaalta puolueet etenkin erityisohjelmissaan määrittelevät kulttuuria laajasti ja esittävät kulttuuripoliittisia tavoitteita tavoilla, jotka eivät rajaudu opetus- ja kulttuuriministeriön hallinnoimaan kulttuurisektoriin tai hallinnonalaan. Etenkin vihreät, Vasemmistoliitto ja SDP nostavat esiin teemoja, jotka hallinnossa kuuluvat esimerkiksi koulutus-, ympäristö-, sosiaali-, työ- ja viestintäpolitiikan sektoreille. Niin vihreät, Va- 
semmistoliitto kuin SDP käsittelevät ohjelmassaan esimerkiksi mediapolitiikkaa ja Yleisradiota (YLE). Vasemmistoliitto (2018) määrittelee ohjelmassaan käsitellyn kulttuurin seuraavasti: "Kulttuuri, josta tässä asiakirjassa puhutaan, on yhteiskunnan vuorovaikutussuhteiden summa. Se sisältää taiteen lisäksi median, keskustelun, vuorovaikutuksen rakenteet ja ilmapiirin.” Keskusta painottaa taidetta ja kulttuuria kestävässä kehityksessä sekä kulttuurin merkityksen ymmärtämistä ja edistämistä poikkihallinnollisesti. Kokoomus pysyttelee linjauksessaan lähinnä kapeasti ymmärretyn kulttuurihallinnon kysymyksissä, mutta laventaa sitä esimerkiksi luovia aloja sekä kirjastoja koskevalla keskustelulla.

Aiemmassa tutkimuksessa (ks. Nousiainen, 1998, s. 74-89) tunnistetut peruserot puolueiden tavoitteissa ja asenteissa näkyvät eri tavoin puolueohjelmien taide- ja kulttuuripoliittisissa tavoitteissa ja painotuksissa. Näihin kuuluvat SDP:n hyvinvointivaltion ideologia (julkinen valta kulttuurisen tasa-arvon mahdollistajana), vasemmistoliiton yksilön vapaus markkinalogiikasta (julkisen sektorin leikkausten arvostelu, perustulo), kristillisdemokraattien arvopohja (kristillinen kulttuuriperintö), RKP:n kaksikielinen kulttuuri (ruotsinkielisten instituutioiden asema), keskustan alueellinen näkökulma (paikalliskulttuurit, kuntien ja alueiden omaleimaisuus), kokoomuksen yksilönvapaus ja markkinatalous (esim. luovien alojen kasvu ja työlliset, kulttuuritapahtuminen byrokratian purkaminen, "kannustava" rahoitus) sekä vihreiden ekologisuus ja tasa-arvo (kulttuurinen moninaisuus, perustulo). Kulttuuripolitiikkaan heijastuvat siten laajasti myös muut kuin puolueiden eksplisiittisesti taidetta ja kulttuuria koskevat näkemykset.

Puolueiden ja toisaalta valtion rooli kulttuuripolitiikassa ei ole vakio. Esimerkiksi puolueiden ideologiat julkisen talouden suhteen (linjaukset talouspolitiikan "sektorilla") vaikuttavat myös kulttuuripolitiikkaan: ei ole kulttuurikehityksen (ja kulttuuripolitiikan erilaisten tavoitteiden toteutumisen) kannalta yhdentekevää, pyritäänkö yleisesti leikkaamaan ja säästämään vai kasvattamaan julkisen rahoituksen määrää. Esimerkiksi taiteen autonomia on nykyjärjestelmän keskeinen piirre, mutta ei itsestäänselvyys. On poliittinen kysymys, nähdäänkö nimenomaan julkisen sektorin vai markkinaehtoisuuden takaavan taiteen autonomian (ks. Häyrynen, 2015). Toisaalta huolimatta puolueiden taiteen autonomiaa koskevista näkemyksistä myös valtion taidehallinnon erilaisiin instrumentalismia sisältäviin pyrkimyksiin kuten tulosohjausprosesseihin ja taidepoliittisesti ohjaaviin projektikohtaisiin avustuksiin voi kytkeytyä taiteen autonomian kannalta arveluttavia piirteitä (Karttunen \& Aaltonen, 2015). Puolueet ja valtio voivat näkökulmasta riippuen edustaa taiteen ja kulttuurin suojaavaa tukea tai torjuttavaa uhkaa.

Mitä tämä kaikki sitten tarkoittaa käytännössä? Puolueet ovat keskeisiä kulttuuripoliittisia vaikuttajia, joilla on valtaa niin informaation ja linjausten tuottajina kuin intressien välittäjinä. Hallituspuolueiden omia ja niiden kanavoimia tavoitteita tiivistyy hallitusohjelmaan, jota pannaan täytäntöön hallinnon kautta. Esimerkiksi keväällä 2015 taiteen ja kulttuurin saavutettavuus poimittiin keskustan kulttuuriin liittyvistä tavoitteista Sipilän hallituksen kärkihankkeeksi, jota ryhdyttiin toteuttamaan opetus- ja kulttuuriministeriön kautta. Tuoreimmista linjauksista Antti Rinteen hallituksen ohjelmaan päätyi esimerkiksi jälleen keskustan kärkitavoite uuden luovia aloja ja kulttuuria tukevan rahaston perustamisesta. Ohjelmilla on siten kulttuuripoliittista merkitystä. Samaan aikaan puolueet ovat ohjelmakatsauksen perusteella kulttuuripolitiikassaan hyvin samoilla linjoilla nykyjärjestelmän ja hallinnon kanssa. Tämä korostaa kulttuuripolitiikan vahvaa jatkuvuutta sekä hallintoa politiikan yli. Kulttuuripolitiikan "poliittisuuden" näkökulmasta on keskeistä, miten valmis kulttuuripolitiikan institutionalisoitunut sektorihallinto on tunnistamaan ja omaksumaan puolueiden kautta kanavoituvia, hallinnon organisaatiotodellisuuden ylittäviä kulttuurisia avauksia ja tarpeita. 


\section{Lähteet ja kirjallisuus}

\section{Tutkimusaineisto}

\section{Kevään 2019 eduskuntavaaliohjelmat}

Kansallinen Kokoomus: Luotamme Suomeen Kristillisdemokraatit: Suomi, johon voit luottaa Perussuomalaiset: Äänestä Suomi takaisin Ruotsalainen kansanpuolue: Mera tillsammans Sininen tulevaisuus: Siniset turvaa

Suomen Keskusta: Suomen arvoisia tekoja

Suomen Sosialidemokraattinen puolve: Tulevaisuuslinja

Vasemmistoliitto: Oikeudenmukainen Suomi kaikille, ei harvoille

Vihreä liitto: Millaisen huomisen haluat rakentaa? Näytä luontosi ja äänestä!

\section{Tuoreimmat kulttuuripoliittiset erityisohjelmat}

Kansallinen Kokoomus (2019): Uutta luova Suomi. Kokoomuksen visio taiteen ja kulttuurin tulevaisuudesta.

Kristillisdemokraatit (2009): Hyvinvointia kulttuurista - Kristillisdemokraattien kulttuuripoliittinen ohjelma.

Ruotsalainen kansanpuolue (2015): Kulturpolitiskt program för Svenska folkpartiet i Finland.

Suomen keskusta (2018): Tulevaisuuden tärkein kasvuala on sivistys. Keskustan kulttuuritavoitteet 2019-2023.

Suomen Sosialidemokraattinen puolve (2018): Kulttuuri kuuluu kaikille

Vasemmistoliitto (2018): Vasemmistoliiton taideja kulttuuripoliittinen ohjelma.

Vihreä liitto (2018): Kulttuuripoliittinen ohjelma.

\section{Tutkimuskirjallisuus}

Aarnio, E. \& Kanerva, J. (toim.) (1995): Puolueohjelmatutkimuksen nykysuunnat. Jyväskylä: Jyväskylän yliopiston valtio-opin laitoksen julkaisuja 69.

Aarnio, E. (1998). Päämäärät liikkeessä. Puolveohjelmien kirjoittamisen muuttuvat merkitykset Suomessa 1950-luvulta 1990-luvulle. Jyväskylä: Jyväskylän yliopisto.

Borg, O. (1965). Suomen puolueet ja puolveohiel- mat 1880-1964. Helsinki: WSOY.

Borg, O. (1995). Ohjelmatutkimuksen ja ohjelmakirjoituksen perinteestä ja muutoksesta. Teoksessa E. Aarnio \& J. Kanerva (toim.) Puolueohjelmatutkimuksen nykysuunnat. Jyväskylä: Jyväskylän yliopiston valtio-opin laitoksen julkaisu 69.

Gustafsson, M. (2019). Kulttuuri ei juuri vaaliohjelmissa näy - Kysyimme suoraan puolveilta, mitä ne pitävät kulttuurissa tärkeänä. Yle Uutiset 10. 4. 2019, URL: https://yle.fi/uutiset/3-10725042 (Haettu 15. 4. 2019.)

Gronow, P. (1976). Kulttuuripolitiikan käsikirja. Helsinki: Otava.

Häyrynen, S. (2006). Suomalaisen yhteiskunnan kulttuuripolitiikka. Jyväskylä: Minerva Kustannus.

Häyrynen, S. (2015). Kulttuuripolitiikan liikkuvat rajat. Kulttuuri suomalaisessa yhteiskuntapolitiikassa. Helsinki: Suomalaisen Kirjallisuuden Seura.

Kangas, A. (1991). Kunta, taide ja markat. Helsinki: Valtion painatuskeskus.

Kangas, A. (1999). Kulttuuripolitiikan uudet vaatteet. Teoksessa A. Kangas \& J. Virkki (toim.): Kulttuuripolitiikan uudet vaatteet (156-178). Jyväskylä: Jyväskylän yliopisto.

Kangas, A. \& Pirnes, E. (2015). Kulttuuripoliittinen päätöksenteko, lainsäädäntö, hallinto ja rahoitus. Teoksessa I. Heiskanen \& A. Kangas \& R. Mitchell (toim.) Taiteen ja kulttuurin kentät, Perusrakenteet, lainsäädäntö ja uudet haasteet (23-108). Helsinki: Tietosanoma.

Kantokorpi, O. (2015). Taiteen puolueettomuuspolitiikkaa. Kulttuurilehti Mustekala. Taide ja puoluepolitiikka, 1:2015, vol. 58. URL: http:// mustekala.info/teemanumerot/taide-ja-puoluepolitiikka-1-15-vol-58/taiteen-puolveettomuuspolitiikkaa/

Karlsson, F. \& Wiberg, M. (2010). Puolueilla on eroja! Periaateohjelma-analyysi. Politiikka. Valtiotieteellisen yhdistyksen julkaisu 52:1, 54-66.

Karttunen, S. \& Aaltonen, T. (2015). Suomalainen taiteilijapolitiikka: apurahatuesta perusoikeuksien toteuttamiseen. Teoksessa I. Heiskanen \& A. Kangas \& R. Mitchell (toim.) Taiteen ja kulttuurin kentät, Perusrakenteet, lainsäädäntö ja uudet haasteet (231-309). Helsinki: Tietosanoma.

Kemppi, E. (2015). Tehdäänkö tällä hetkellä taidepolitiikkaa? Keskustelu taidepolitiikan asiantuntija Pauli Rautiaisen kanssa. Kulttuurilehti Mustekala. Taide ja puoluepolitiikka, 1:2015, vol. 58. URL: http://mustekala. info/teemanumerot/taide-ja-puolvepolitiik- 
ka-1-15-vol-58/

Kulttuurilehti Mustekala. Taide ja puolvepolitiikka, 1:2015, vol. 58. URL: http://mustekala. info/teemanumerot/taide-ja-puoluepolitiikka-1-15-vol-58/

Lappalainen, P. (2006). Puolveohielmien merkitys. Teoksessa J. Paastela \& H. Paloheimo (toim.) Suomen puolveiden periaateohjelmat. Ohjelmat, niiden taustaa ja tarkastelua (259-275). Tampere: Tampereen yliopisto, Politiikan tutkimuksen laitos.

Mertanen, T. (2008). Harkinnanvaraisuudesta lakisääteiseen. Suomen valtiollisen taidehallinnon sekä taiteenalojen tukijäriestelmien muotoutuminen 1960-1980-luvulla. Helsinki: Kulttuuripoliittisen tutkimuksen edistämissäätiö.

Mykkänen, J. (2017). Kuka päättää hyvinvointimallin tulevaisuudesta? Teoksessa J. Kananen (toim.) Kilpailuvaltion kyydissä. Suomen hyvinvointimallin tulevaisuus (97-127). Helsinki: Gaudeamus.

Nousiainen, J. (1998). Suomen poliittinen järjestelmä. Helsinki: WSOY.

Opetus- ja kulttuuriministeriö. (2018). Kulttuurija taidepolitiikkaa koskevat hallitusohjelmaesitykset vuosille 2019-2023. Opetus- ja kulttuuriministeriö, Kulttuuri- ja taidepolitiikan osasto 6.11.2018.

Paastela, J. \& Paloheimo, H. (toim.). (2006). Suomen puolveiden periaateohielmat. Ohjelmat, niiden taustaa ja tarkastelua. Tampere: Tampereen yliopisto, Politiikan tutkimuksen laitos.

Rautiainen, P. (2008). Suomalainen taiteilijatuki. Valtion suora ja välillinen taiteilijatuki taidetoimikuntien perustamisesta tähän päivään. Helsinki: Taiteen keskustoimikunta.

Saukkonen, P. (2014). Vankka linnake, joustava sopeutuja vai seisova vesi? Suomalaisen kulttuuripolitiikan viimeaikainen kehitys. Kulttuuripoliiittisen tutkimuksen edistämissäätiö Cuporen verkkojulkaisuja 23/2014.

Sokka, S. (2014). Fakkiutunut hallinto ei ymmärrä kulttuuripoliittista valtaa. Tiede ja edistys, 39 (3), 214-224.

Sundberg, J. (2012). Puolueet yhteiskunnan ohjaajina ja ohjattuina. Teoksessa K. Paakkunainen (toim.) Suomalaisen politiikan murroksia ja muutoksia (115-136). Helsinki: Helsingin yliopisto, politiikan ja talouden tutkimuksen laitos.

Tuomikoski-Leskelä, P. (1977). Taide ja politiikka. Helsinki: Suomen historiallinen seura.

Valtioneuvoston kanslia. (2015). Ratkaisujen Suomi. Pääministeri Juha Sipilän hallituksen strateginen ohjelma. https://valtioneuvosto.fi/ documents/10184/1427398/Ratkaisujent-
Suomi_FI_YHDISTETTY_netti.pdf

Valtioneuvoston kanslia. (2019). Osallistava ja osaava Suomi - sosiaalisesti, taloudellisesti ja ekologisesti kestävä yhteiskunta. Pääministeri Antti Rinteen hallituksen ohjelma. https://valtioneuvosto.fi/rinteen-hallitus/hallitusohielma

Wiberg, M. (2006). Politiikka Suomessa. Porvoo: WSOY. 


\section{Loppuviitteet}

1. Tämä ehdotus on kirjattu myös keskustan viralliseen kulttuurilinjaukseen marraskuussa 2018.

2. Suomen puoluejärjestelmä heijastaa ideologisia jakoja, joiden taustalla ovat kolme keskeistä aatesuuntaa eli kantaideologiaa: konservatismi, liberalismi ja sosialismi. Karkeasti konservatismin juuret ovat säilyttämisen aatteessa, liberalismin vapausaatteessa ja sosialismin yhteiskunta-aatteessa. (Paastela \& Paloheimo, 2006, s. 2-3.)

3. "Pienten askelten politiikkaa" luonnehtivat Rautiaisen mukaan vähittäisten resurssilisäysten, poliittis-hallinnollisen ohjausjärjestelmän instrumentalismin vahvistumisen ja taidehallinnon organisaatiorakenteen hienojakoistumisen trendit.
4. Käytännössä valtion tuki taiteelle ja kulttuurille on yhteenlaskettuna jo yli prosentin, jos mukaan lasketaan esimerkiksi kulttuurin rahoitus valtiovarainministeriön asukaskohtaisista valtionosuuksista (kirjastot, taiteen perusopetus, yleinen kulttuuritoiminta). Opetus- ja kulttuuriministeriön talousarvioon sisältyy muitakin määrärahoja, jotka voidaan ajatella kuuluvan taiteen ja kulttuurin budjettiin.

5. Kulttuuriohjelmissaan ja esimerkiksi YLE:n kyselyssä prosentti kulttuurille -tavoitteeseen on sitoutunut useita puolueita. Esimerkiksi kokoomus kannattaa asiaa kulttuurivisiossaan, joka linkitettiin maaliskuussa 2019 osaksi puolueen eduskuntavaaliohjelmaa. 
Liite 1. Katsaus puolveiden uusimpien (2018-2019) kulttuuripoliittisten ohjelmien teemoihin, tavoitteisiin ja keinoihin.

\begin{tabular}{|c|c|c|c|}
\hline Puolve & $\begin{array}{l}\text { Kulttuuriohjelman temaat- } \\
\text { tisten osioiden / tavoiteal- } \\
\text { veiden määrä }\end{array}$ & $\begin{array}{c}\text { Kulttuuriohjelman teemat } \\
\text { tavoitealueet }\end{array}$ & $\begin{array}{l}\text { Keinojen / toimen- } \\
\text { piteiden määrä } \\
\text { (kyseisen teeman alla) }\end{array}$ \\
\hline \multirow[t]{5}{*}{ Suomen Keskusta } & 5 & Lapset ja nuoret & 3 \\
\hline & & Kärkitavoite & 1 \\
\hline & & Kulttuuripolitiikan kehittäminen & 3 \\
\hline & & Taiteilijat ja taidepolitiikka & 3 \\
\hline & & Taide ja kestävä kehitys & 1 \\
\hline \multirow[t]{3}{*}{$\begin{array}{l}\text { Kansallinen } \\
\text { Kokoomus }\end{array}$} & 3 & $\begin{array}{l}\text { Läpinäkyvä, luovuuteen kannustava } \\
\text { rahoitus }\end{array}$ & 7 \\
\hline & & Kasvua luoville aloille & 6 \\
\hline & & Taide ja kulttuuri kaikkien saataville & 9 \\
\hline \multirow[t]{8}{*}{ Vasemmistoliitto } & 8 & Saavutettavuus ja yhdenvertaisuus & 11 \\
\hline & & Kulttuurinen moninaisuus & 10 \\
\hline & & Taiteilijoiden asema & 12 \\
\hline & & $\begin{array}{l}\text { Luovien alojen itsensätyöllistäjien } \\
\text { asema }\end{array}$ & 4 \\
\hline & & Tekijänoikeudet & 3 \\
\hline & & Taiteen ja kulttuurin rakenteet & 11 \\
\hline & & Media ja ilmaisunvapaus & 6 \\
\hline & & Ympäristö ja kulttuuriperintö & 9 \\
\hline \multirow[t]{19}{*}{ Vihreä liitto } & 28 & Kulttuuripalvelujen saavutettavuus & 9 \\
\hline & & Monipuoliset kulttuuripalvelut & 4 \\
\hline & & Kirjastot kulttuurin kivijalkana & 6 \\
\hline & & Omaehtoinen kulttuuritoiminta & 4 \\
\hline & & $\begin{array}{l}\text { Kulttuurinen monimuotoisuus ja } \\
\text { tasa-arvo }\end{array}$ & 7 \\
\hline & & $\begin{array}{l}\text { Digitaalisuus saavutettavuuden } \\
\text { edistäjänä }\end{array}$ & 1 \\
\hline & & $\begin{array}{l}\text { Kunnat taiteen ja kulttuurin rahoit- } \\
\text { tajina }\end{array}$ & 6 \\
\hline & & Valtionosuusiärjestelmä & 7 \\
\hline & & Prosenttiperiaate & 4 \\
\hline & & Yleisradion rahoitus ja tehtävät & 2 \\
\hline & & $\begin{array}{l}\text { Rahapelien tuotto kulttuurin raho- } \\
\text { ituksena }\end{array}$ & 1 \\
\hline & & Taiteilija-apurahat & 4 \\
\hline & & Taiteilija-allianssi & 1 \\
\hline & & $\begin{array}{l}\text { Taiteilijan työllisyys ja toimeentulo } \\
\text { luovilla aloilla }\end{array}$ & 5 \\
\hline & & $\begin{array}{l}\text { Eläkkeet ja apurahojen sosiaali- } \\
\text { turva }\end{array}$ & 4 \\
\hline & & $\begin{array}{l}\text { Kuvataiteen rakenteet ja näyttely- } \\
\text { palkkiojärjestelmä }\end{array}$ & 5 \\
\hline & & $\begin{array}{l}\text { Luovista aloista taloudellista hyvin- } \\
\text { vointia }\end{array}$ & 2 \\
\hline & & Toimiva ja osaava välittäiäporras & 3 \\
\hline & & Tekijänoikeuskorvaukset & 5 \\
\hline
\end{tabular}




\begin{tabular}{|c|c|c|c|}
\hline Puolue & $\begin{array}{l}\text { Kulttuuriohjelman temaat- } \\
\text { tisten osioiden / tavoiteal- } \\
\text { veiden määrä }\end{array}$ & $\begin{array}{c}\text { Kulttuuriohjelman teemat } \\
\text { tavoitealueet }\end{array}$ & $\begin{array}{c}\text { Keinojen / toimen- } \\
\text { piteiden määrä } \\
\text { (kyseisen teeman alla) }\end{array}$ \\
\hline & & Luovien alojen vienti & 3 \\
\hline & & $\begin{array}{l}\text { Taito- ja taideaineet varhaiskas- } \\
\text { vatuksessa ja perusopetuksessa }\end{array}$ & 4 \\
\hline & & Taiteen perusopetus & 5 \\
\hline & & $\begin{array}{l}\text { Kerhotoiminta ja kulttuurin } \\
\text { harrastaminen }\end{array}$ & 2 \\
\hline & & Vapaa sivistystyö & 2 \\
\hline & & Toisen asteen ammatillinen koulutus & 4 \\
\hline & & Taidealojen korkeakoulutus & 5 \\
\hline & & Kulttuuri ja hyvinvointi & 6 \\
\hline & & Rakennetun ympäristön laatu & 7 \\
\hline & & Monimuotoinen kulttuuriperintö & 6 \\
\hline \multirow{20}{*}{$\begin{array}{l}\text { Suomen Sosiali- } \\
\text { demokraattinen } \\
\text { Puolve (SDP)* }\end{array}$} & \multirow[t]{20}{*}{20} & Kaikki alkoi työväentalolta & $x$ \\
\hline & & Elämää luokkayhteiskunnassa & $x$ \\
\hline & & Ilmaista, edullista ja maksullista & $\mathrm{x}$ \\
\hline & & Monien kulttuurien Suomi & $x$ \\
\hline & & Vapaampaa taidetta & $x$ \\
\hline & & Kaikki tekee, jokainen osaa & $\mathrm{x}$ \\
\hline & & Rakkaat ympäristöt & $x$ \\
\hline & & Kulttuuritoimijoiden rahoitus & $x$ \\
\hline & & Taiteilijaköyhyyttä vastaan & $\mathrm{x}$ \\
\hline & & Uuden ajan kulttuurilaitoksia & $x$ \\
\hline & & Meidän yhteinen Yleisradio & $x$ \\
\hline & & Kaikkein paras kirjasto & $x$ \\
\hline & & Taidekasvatusta jokaiselle & $x$ \\
\hline & & Joutilaat tilat käyttöön & $\mathrm{x}$ \\
\hline & & Kulttuuri luo hyvinvointia & $\mathrm{x}$ \\
\hline & & Lääke syriäytymiseen & $x$ \\
\hline & & Kulttuuriyrittäjät ja alustatalous & $x$ \\
\hline & & Kasvua luovilta aloilta & $x$ \\
\hline & & Tuottoja turismista & $x$ \\
\hline & & Työllisyys ja taiteilijoiden koulutus & $x$ \\
\hline \multirow{9}{*}{$\begin{array}{l}\text { Suomen ruotsa- } \\
\text { lainen kansan- } \\
\text { puolve (RKP) }\end{array}$} & \multirow[t]{9}{*}{9} & Kultur och tillgänglighet & 3 \\
\hline & & Kultur och kompetens & 4 \\
\hline & & Kulturarvet & 2 \\
\hline & & Kultur och språk & 2 \\
\hline & & Kultur och media & 4 \\
\hline & & $\begin{array}{l}\text { Kultur för, med och av barn och } \\
\text { unga }\end{array}$ & 3 \\
\hline & & Kultur och samhälle & 4 \\
\hline & & Kulturen är många kulturer & 3 \\
\hline & & Kultur i världen & 2 \\
\hline
\end{tabular}

* SDP:n erityisohjelmassa ei esitetä yksittäisiä toimenpiteitä vaan kuvataan laajemmin tavoitteita ja visioita kulttuuripolitiikkaan liittyen. 


\begin{tabular}{|c|c|c|c|}
\hline Puolve & $\begin{array}{l}\text { Kulttuuriohjelman temaat- } \\
\text { tisten osioiden / tavoiteal- } \\
\text { veiden mäc̈rä }\end{array}$ & $\begin{array}{c}\text { Kulttuuriohjelman teemat } \\
\text { tavoitealueet }\end{array}$ & $\begin{array}{c}\text { Keinojen / toimen- } \\
\text { piteiden määrä } \\
\text { (kyseisen teeman alla) }\end{array}$ \\
\hline \multirow[t]{13}{*}{$\begin{array}{l}\text { Suomen Kristillis- } \\
\text { demokraatit (KD) }\end{array}$} & 12 & $\begin{array}{l}\text { Maamme kulttuurinen } \\
\text { monimuotoisuus }\end{array}$ & 9 \\
\hline & & Kehityspolitiikka ja kehitysyhteistyö & \\
\hline & & Taidetoimikunnat & \\
\hline & & Varhaiskasvatus ja perusopetus & \\
\hline & & Vapaa sivistystyö & \\
\hline & & Taiteen perusopetus & \\
\hline & & Toinen aste & 22 \\
\hline & & Ammattikorkeakoulut & \\
\hline & & Taideyliopistot ja -korkeakoulut & \\
\hline & & Media & \\
\hline & & $\begin{array}{l}\text { Kulttuuripolitiikkaa kunnissa / } \\
\text { maakunnissa }\end{array}$ & 13 \\
\hline & & $\begin{array}{l}\text { Yrittäiyys ja kulttuurivienti sekä } \\
\text { kulttuurialan työsuhteet }\end{array}$ & 5 \\
\hline & & Toimenpiteitä yhteensä & 299 \\
\hline
\end{tabular}

